\title{
外傷性末梢神経障害の治療とそのリハビリテー ション治療の実際一腕神経叢損傷一
}

\author{
$\left[\begin{array}{l}\text { Surgical Treatment and Postoperative Rehabilitation Therapy for } \\ \text { Traumatic Peripheral Injury : Brachial Plexus Injury }\end{array}\right]$
}

柿木良介* Ryosuke Kakinoki

近畿大学医学部整形外科学教室

Key words : 腕神経叢損傷／リハビリテーション治療／神経再建術／筋肉移植術

\section{はじめに}

腕神経叢は, 第 5 頚髄神経根から第 1 胸髄神経 の 5 本の神経根から形成されるが，ときに第 4 頚 髄神経根や第 2 胸髄神経根が関与する症例があ り,それぞれ, prefixed, postfixed と呼ばれてい る. 腕神経叢損傷は, この腕神経叢部の神経障害 である．腕神経叢損傷は，節前損傷と節後損傷に 大別される．節前損傷は後根神経節より中枢での 損傷で, 神経根の引き抜き損傷のことである。一 方, 節後損傷は, 後根神経節より末梢に発生した 末梢神経障害であり, その損傷および術後の経過 は, Seddon 分類 ${ }^{1)}$ に従う（表 1). 神経根引き抜き 損傷では，一般に引き抜かれた神経根を単に脊䯣 に綘着しても, 神経再生はほとんど起こらないとさ れていて, その治療は, 副神経, 横隔神経, 肋間神 経などを麻痺神経に移行する神経移行術や麻痺を 免れた筋肉を移行する筋移行 (移植) 術が適応と なる，一方，節後損傷は，末梢神経損傷であるの で, 神経縫合術, 神経移植術もその適応となる. 腕神経叢損傷の発生原因としては, オートバイに よる転倒など高エネルギー外傷がほとんどで，とき に腕神経叢部への刺創, 医原性損傷などがある.

* 近畿大学医学部整形外科学教室

( 589-8511 大阪府大阪狭山市大野東 377-2)

E-mail : rkakinoki@med.kindai.ac.jp

DOI : 10.2490/jjrmc.55.939
本論文では，第 5 頚髄神経根から第 1 胸髄神経の 5 本の神経根すべての引き抜き損傷である全型腕 神経叢損傷に焦点を置いて, 筆者の行っている外 科的治療とリハビリテーション治療を説明する。

\section{全型腕神経叢引き抜き損傷}

1. 神経移行, 移植術亡筋肉移行, 移植術

一般的に神経移行, 移植術は, 受傷後 6 力月以 内の損傷に適応があり, 筋肉移行, 移植術は合併 する脳損傷などの影響などで診断が遅れ, 受傷後 6 力月以上経った症例が適応となる. 6 力月以上 脱神経状態が続くと, 筋の線維化, 神経筋接合部 の変性が進み, 神経再建しても良好な運動回復が 期待されないからである、ただし，最近では全型 腕神経叢損傷の治療として, 積極的に手指運動の 再建を行うようになり, その場合は遊離筋肉移植 が適応となる.

\section{2. 外科的治療}

手術法にはいくつかあるが, ここでは Doi らの開

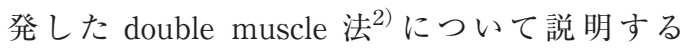
(図 1).この術式は, 両側薄筋を用いて, 时屈曲お よび手指伸展と手指屈曲を再建し, 交差神経移行 術にて, 肩, 肩甲骨機能, 时関節伸展機能, 手指知 覚機能を再建する方法である. 移行する神経とし ては, 肋間神経, 副神経, 横隔神経, ときに健側の 
第 7 頚髄神経根を用いる.

\section{1) 第 1 回目手術}

健側下肢から支配神経である閉鎖神経，栄養動 脈である内側大腿回旋動静脈をつけた薄筋を採取 し，薄筋の中枢を患側鎖骨に，末梢を患肢総指伸 筋と長母指伸筋に縫合する．薄筋の閉鎖神経を移 植部の副神経と, 内側大腿回旋動静脈を胸肩峰動 静脈と顕微鏡下で縫合する，次に，横隔神経を麻 痺した肩甲上神経と縫合し，腱板機能を回復させ る.

\section{2）第 2 回目手術}

患側下肢より第 1 回目と同様に薄筋を採取し, 薄筋の中枢を第 2,3 肋骨に, 未梢を長母指屈筋お よび深指屈筋に縫合して指屈曲機構を再建する. 薄筋の閉鎖神経は患側の第 2,3 肋間神経と, 内側

\section{表 1 末梢神経障害の分類（Seddon の分類）}

\section{1 度 Neurapraxia（一過性神経伝導障害）}

髄鞘のみの損傷一自然回復可能

2 度 Axonotmesis (軸索の断裂)

Tinel 徵候がみられる一ときとして自然回復可能

3 度 Neurotmesis (完全断裂)

損傷部位より遠位で Waller 変性が起こる一自然回復は 困難
大腿回旋動静脈は胸背動静脈と縫合する．第 4,5 肋間神経を橈骨神経上腕三頭筋枝へ移行して肘関 節伸展機能を再建し, さらに第 6 肋間神経を長胸 神経に移行して肩甲骨の安定化を図る。採取した 肋間神経外側枝（知鸴神経主体）は損傷腕神経叢 の外側神経束から分かれる正中神経枝に縫合し， 手指の知覚を再建する.

ときに，健側第 7 神経根を患側後側神経束に縫 合し, 肘伸展機能と肩外転機能を再建する場合も ある3).

その後神経回復を待って, 手指の中手指節 (MP) 関節もしくは近位指節間（PIP）関節の固定術や手 関節の固定術を追加する.

\section{3. 術後リハビリテーション}

\section{1) 運動療法}

筋肉移植の術後 3 週間目から移植筋肉に緊張の かからない範囲で他動肘関節運動を開始する，術 後 5 週目より移植筋に徐々に緊張をかけるように して，他動肘関節運動範囲を拡大させる。また， 肩関節も徐々に可動域を拡大させる。術後 8 週目 より肘関節は，完全屈曲から伸展 $-30^{\circ}$ ぐらいを 目安に可動域を拡大させ, 肩関節も外転, 屈曲 $90^{\circ}$
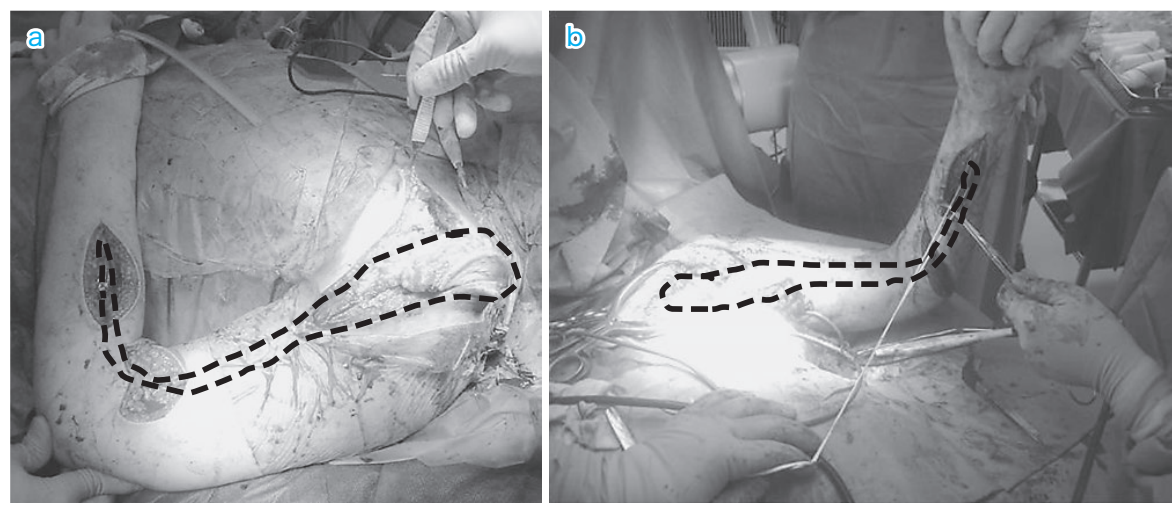

図 1 Double muscle 法

a : 第 1 回目の薄筋移植，遊離薄筋は，鎖骨と総指伸筋腱，長母指伸筋腱の間に移植して，関節屈曲と手指伸展を再建した 遊離薄筋の閉鎖神経は副神経と, 内側大腿回旋動静脈は胸肩峰動静脈と縫合した（破線は移植筋肉）。

$\mathrm{b}$ ：第 2 回目の薄筋移植，遊離薄筋は。第 2 肋骨と深指屈筋腱，長母指屈筋腱の間に移植して，手指屈曲を再建した。遊離 薄筋の閉鎖神経は肋間神経と, 内側大腿回旋動静脈は胸背動静脈と縫合した（破線は移植筋肉）。 
までを目処に拡大させるが，それ以上の可動域の 拡大は行わない。この術式では, 指運動は肘完全 伸展時に可能となるため, 筋肉移植時の时最大伸 展はー30。 までにしておくと ADL 上，手指運動に 有利で, かつ肘関節屈曲トルクが小さくなり肘屈 曲がしやすい.

\section{2）修復神経への電気刺激の影響}

再生神経への電気刺激に関しては, いくつかの 基礎研究がある. Al-Majed $ら^{4)}$ は，外科的に修復 した神経への電気刺激は, 運動神経に対し preferencial motor reinnervation（PMR）を光進させる が，知覚神経では preferencial sensory reinnervation を示さなかったと報告している．また，前角細 胞への電気刺激への影響に関して, Al-Majed $ら^{5)}$

は，神経縫合直後に神経縫合部中枢を supramaximal stimulation で 1 時間, $20 \mathrm{~Hz}, 100 \mu$ 秒で刺激 すると，前角細胞での brain derived neurotrophic factor (BDNF) 発現を増やしたと報告, Geremia $ら^{6)}$ は, 3〜 $5 \mathrm{~V}, 1$ 時間, $20 \mathrm{~Hz}, 100 \mu$ 秒 の刺激は, 後根神経細胞での GAP43 の発現を増 やしたと報告している，以上により，神経修復直 後に修復神経を低周波刺激すると，神経再生は促 進し PMR も充進するようであるが，1 時間に及ぶ 刺激時間を臨床的に使用できるか問題もある.

\section{3）末梢神経再生過程での運動の影響}

Tam らは，ラットで第 4 第 5 腰髄神経引き抜き 損傷モデルを作成し，1日 8 時間運動させた群， 1 日 8 時間 FES (supramaximal pulse, $100 \mu$ 秒, $20 \mathrm{~Hz}$ ) で坐骨神経を刺激した群，ケージ内で運動 させなかった群を作成した。 その結果, 運動群, FES 刺激群の前脛骨筋，腓腹筋での axonal sprouting は, ケージ内で何もさせなかった群より 悪かったと報告している7)。 また，Tam らは，第 4 腰髄神経を引き抜いて，部分的に前脛骨筋を脱神 経させたラットモデルを使って, ケージ内で何も運 動させなかった群と 1 日 8 時間運動させた群を比
較したところ，運動をさせたラットでは，再生神経 から神経再支配されていない endplate に向けての シュワン細胞によるシナプス間架橋形成が不良で あることを報告した ${ }^{8)}$. 部分脱神経筋支配の筋肉 を低周波刺激したり，激しい運動負荷を加えると， 筋肉内の神経の側芽形成を抑制するという研究結 果が示されている.

以上のように, 末梢神経手術後の電気療法, 運 動療法の併用については, 議論の多いところであ るが，筆者は神経再支配が筋肉に起こり筋収縮が 認められようになれば，筋収縮をアシストして筋肉 内の代謝を促す目的で, 低周波刺激, 自動運動を 積極的に行っている.

\section{4) Biofeedback の活用}

Double muscle 法を行った症例では, 患側僧帽 筋に力を入れれば，手指伸展，肘関節屈曲筋に力 が入り，大きな呼吸をして患側胸部に力を入れれ ば, 手指屈曲, 肘伸展筋が作動する. 術後患者で は, この手指, 时関節の伸展および屈曲運動の分 離が神経回復初期に困難となる。手指, 时屈曲筋 と手指，肘伸展筋上に電極を設置し，筋収縮時に 収縮音が流れるようにして, 手指, 肘関節の屈曲, 伸展運動の分離を行っている（図 2).

\section{脳可塑性}

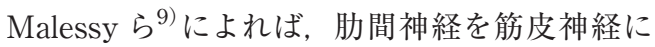
移行し, 时屈曲再建を行った患者に機能的 MRI 検 査を行ったところ, 时屈曲力が回復してくると, 再 建时関節屈曲運動により誘発される脳活動部位 は，受傷以前に肘屈曲時に活動していた部位と同 一であることが示された，われわれは，機能的近 赤外線スペクトロスコピー（NIRS）を用いて, 健側 第 7 頚髄神経根移行 $(\mathrm{CC} 7$ 術 $)$ により患側上肢の 運動神経を再建した患者の脳活動部位を検査した ところ, 術後 $2 \sim 3$ 年の時点では, 患側上肢の再建 運動により患側大脳皮質運動野の活動が誘発され 


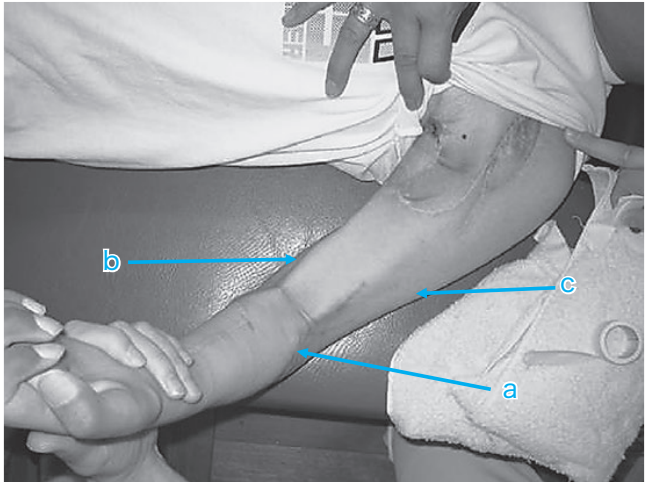

図 2 Double muscle 法術後の biofeedback を 用いたリハビリテーション治療

19 歳, 男性. 左腕神経叢全型引き抜き損傷. Double muscle 法を施行した。1 回目の移植薄筋（a）で左肘屈曲, 手 指伸展を再建 (駆動神経; 左副神経), 2 回目の移植薄筋 (b) で左手指屈曲を再建した（駆動神経; 左肋間神経)。左肘伸 展は，健側の C7 神経根を橈骨神経上腕三頭筋枝に移行し て再建した ( C C 7 術)（c）。左僧帽筋に力を入れて, 左肘屈 曲と手指伸展, 大きな呼吸と左肋間筋に力を入れ左指屈曲, 右側の肘伸展筋に力を入れて左肘伸展を行わせた。 この複 雑な再建運動の分離に biofeedback 装置は効果を発した。

たが， 6〜 7 年経過すると，次第に健側の大脳皮質 運動野の活動が誘発される傾向のあることがわ かった ${ }^{10)}$. すなわち, CC7 術後早期では, 患側上 肢の再建運動は，患側大脳皮質（健側第 7 澒髄神 経根を支配）に支配されているが，時間の経過とと もに，もともと患側上肢運動を支配していた健側 大脳皮質運動野の支配に移行することがわかった。 また，患側上肢の再建運動機能の高い症例ほどこ の傾向が強く, 患側上肢の運動機能の回復不良な 症例では, 術後 6〜 7 年経過した時点でも, 患側上 肢運動で, 患側大脳皮質運動野の活動がみられた. 知覚神経についても同様の傾向がみられ，CC7 術 で再建した患側上肢の知覚刺激では, 術後 $2 \sim 3$ 年 の時点で健側第 7 頚髄神経根支配の患側大脳皮質 体性感覚野が活動していたが, 術後 6〜7 年経過す ると, 知覚回復の良好な症例では，もともと患側上 肢の知覚を支配していた健側大脳皮質体性感覚野 が活動することがわかった ${ }^{10)}$.

以上のように末梢神経から大脳への刺激は，脳
可塑性を誘発し，末梢神経手術後の患者では，こ の脳可塑性を誘発させるためにも未梢からの刺激 の input が大切で, 末梢神経再建術後のリハビリ テーション治療の充実, さらなる科学的分析の必 要性を痛感する.

\section{文 献}

1) Seddon HJ : Surgical disorders of peripheral nerve. Churchill Livingstone, Edinburgh, London, 1972

2) Doi K, Muramatsu K, Hattori Y, Otsuka K, Tan SH, Nanda V, Watanabe M : Restoration of prehension with the double free muscle technique following complete avulsion of the brachial plexus. Indications and long-term results. J Bone Joint Surg Am 2000 ; $82: 652-666$

3) Gu YD, Zhang GM, Chen DS, Yan JG, Cheng XM, Chen L : Seventh cervical nerve root transfer from the contralateral healthy side for treatment of brachial plexus root avulsion. J Hand Surg Br 1992 ; $17: 518-521$

4) Al-Majed AA, Tam SL, Gordon T : Electrical stimulation accelerates and enhances expression of regeneration-associated genes in regenerating rat femoral motoneurons. Cell Mol Neurobiol 2004 ; 24 : $379-402$

5) Al-Majed AA, Brushart TM, Gordon T : Electrical stimulation accelerates and increases expression of $\mathrm{BDNF}$ and trkB mRNA in regenerating rat femoral motoneurons. Eur J Neurosci $2000 ; 12: 4381-4390$

6) Geremia NM, Gordon T, Brushart TM, Al-Majed AA, Verge VM : Electrical stimulation promotes sensory neuron regeneration and growth-associated gene expression. Exp Neurol $2007 ; 205: 347-$ 359

7) Tam SL, Gordon $\mathrm{T}$ : Neuromuscular activity impairs axonal sprouting in partially denervated muscles by inhibiting bridge formation of perisynaptic Schwann cells. J Neurobiol $2003 ; 57: 221-234$

8) Tam SL, Archibald V, Jassar B, Tyreman N, Gordon $\mathrm{T}$ : Increased neuromuscular activity reduces sprouting in partially denervated muscles. J Neurosci $2001 ; 21: 654-667$

9) Malessy MJ, Bakker D, Dekker AJ, Van Duk JG, Thomeer RT : Functional magnetic resonance imaging and control over the biceps muscle after intercostal-musculocutaneous nerve transfer. J Neurosurg $2003 ; 98: 261-268$

10) Kakinoki $R$, Duncan SFM, Ikeguchi $R$, Ohta $S$, Nankaku M, Sakai H, Noguchi T, Kaizawa Y, Akagi $\mathrm{M}$ : Motor and sensory cortical changes after contralateral cervical seventh nerve root $(\mathrm{CC} 7)$ transfer in patients with brachial plexus injuries. J Hand Surg Asian Pac Vol 2017 ; 22 : 138-149 